\title{
Conceitos de habitação social e desenho urbano ambiental no Concurso Renova SP, 2011.
}

\author{
Concepts of social housing and urban design at the Renova SP Competition, 2011.
}

\section{Luana Diana*, Patrícia Rodrigues Samora**}

*Graduanda do curso de Arquitetura e Urbanismo na Pontifícia Universidade Católica de Campinas. Integrante do grupo de pesquisa "Arquitetura, Urbanismo e as favelas: práticas, inovação, teoria e crítica na produção brasileira no século XXI", lua_na9@hotmail.com

**Arquiteta e Urbanista, docente e pesquisadora no programa de Pós Graduação em Arquitetura e Urbanismo e na graduação em Arquitetura e Urbanismo na Pontifícia Universidade Católica de Campinas. Integrante do grupo de Pesquisa "Políticas Territoriais e a Água no Meio urbano". É Pós Doutora (2014) e Doutora pela FAUUSP (Habitat 2010), patricia.samora@puc-campinas.edu.br

\section{Palavras-chave:}

Habitação de interesse social;

Desenho urbano ambiental;

Assentamentos precários.

\section{Keywords:}

Social housing;

Urban environmental design

Precarious settlements.

\section{Resumo}

Este artigo discute as dezessete propostas premiadas no Concurso Renova SP (2011). Tendo em vista a complexidade do tema do concurso, a urbanização de Perímetros de Ação Integrada em áreas com assentamentos precários, o presente trabalho reconheceu e sistematizou as diretrizes do concurso e as soluções premiadas, enfocando os temas das soluções para a habitação e o meio ambiente urbano. A análise das soluções habitacionais considerou aquelas relativas ao o espaço habitado, composto pelas moradias autoconstruídas pelos moradores e pelos novos conjuntos habitacionais destinados à população removida pelas obras. As soluções para o meio ambiente urbano são aquelas que impactam a morfologia preexistente, com foco em macrodrenagem, manejo das águas urbanas e desenho para as áreas de preservação permanente ocupadas por moradias em risco. O referencial teórico sobre estes temas foi utilizado para a análise tanto das diretrizes do concurso, formulada pelos organizadores, quanto dos projetos premiados. Os resultados contribuem para compreender a visão contemporânea quanto aos problemas habitacionais e ambientais presentes nos assentamentos precários e o papel da Arquitetura e Urbanismo como campo de ensaios, tendo por paradigma a sustentabilidade urbana e justiça social na integração das favelas à cidade.

\section{Abstract} Competition (2011). Given the complexity of the contest theme, the urbanization of the Integrated Perimeters of Action in urban areas having precarious settlements, the present work recognized and systematized the call guidelines and awarded solutions, focusing on the themes of solutions for housing and the environment urban. The analysis of the housing solutions considered those related to the inhabited space, composed by the self-built houses and the new housing developments or the population intended to be removed by the works. The urban environment solutions are those that impact the preexisting morphology, with a focus on macro drainage, urban water management and the design for permanent preservation areas occupied by at-risk dwellings. The theoretical framework on these themes has supported the analyze both the competition guidelines, formulated by the organizers and the awarded projects. The results contribute to understanding the current view regarding housing and environmental problems present in precarious settlements and the role of Architecture and Urbanism as a testing tice in the integration of favelas into the city. 


\section{Introdução}

Os assentamentos urbanos informais brasileiros abrigam grande parte da população de baixa renda e uma porção significativa dessas ocupações ocorrem em áreas ambientalmente sensíveis e impróprias para fins habitacionais. Segundo dados do IBGE 2020, o Brasil possui 13.151 aglomerações subnormais localizados em 734 municípios, totalizando em 5.12.747 domicílios, sendo que 1.066.813 estão no estado de São Paulo. O adensamento populacional e construtivo excessivo e o constante incremento populacional das favelas impõem uma complexidade adicional às intervenções promovidas por políticas públicas nestes locais. As intervenções de urbanização de favelas buscam prover as áreas precárias de segurança quanto à riscos e a remoções forçadas, infraestrutura básica e qualidade de vida dos moradores. Na sua dimensão ambiental (DENALDI, FERRARA, 2018; FERRARA et al, 2019), incluem ações sobretudo de saneamento, contenções de encostas e macrodrenagem de canais degradados, entre outras. Quanto ao espaço habitado, as medidas podem ser legais, como a regularização fundiária dos lotes, ou no âmbito do espaço construído, como a reforma, remoção e reconstrução de moradias. Neste trabalho, serão discutidas apenas as medidas físicas no âmbito da habitação em favelas.

Este conjunto de ações vêm sendo praticadas há décadas no Brasil e seus resultados são reconhecidos internacionalmente. Dentre os impactos resultantes, a remodelação muitas vezes é significativa, sendo objeto de interesse do campo do conhecimento da Arquitetura e Urbanismo. Durante o século XX, o tema foi amplamente debatido na América Latina (FERNANDES, 2018; BARRETO, 2018) e o continente abrigou diversas práticas, algumas reconhecidas como "best practices" na II Conferência Habitat da ONU em Istambul (1986). No Brasil, os concursos de projeto foram decisivos para fomentar respostas estéticas e tecnológicas ao tema, movimentando assim a disciplina da Arquitetura e Urbanismo.

O objetivo deste artigo é discutir criticamente a produção contemporânea da Arquitetura e Urbanismo quanto ao desenvolvimento de soluções para os assentamentos precários urbanos. O tema escolhido foi a produção premiada do concurso de projeto "Renova SP" realizado em 2011 pela prefeitura de São Paulo e o Instituto de Arquitetos do Brasil, que selecionou dezessete equipes. O recorte enfocou as propostas projetuais, já que é comum ocorrer modificações posteriores impostas pelos limites do programa habitacional responsável pela implantação das obras.

Como premissa, assumimos que os pressupostos da justiça social e sustentabilidade urbana são indissociáveis. Porém, considerando que os projetos de urbanização de favelas são multidisciplinares e complexos, adotamos um recorte para a análise dos dados primários, considerando as soluções para o espaço habitado e o desenho ambiental e urbano, para verificar como os organizadores do concurso e as equipes vencedoras entendem estes temas. Estes também nortearam o referencial teórico adotado e aplicado na análise das diretrizes do concurso e nas soluções de projeto.

O objetivo principal deste trabalho foi observar como arquitetos e urbanistas entendem a urbanização de favelas. Faz parte de um trabalho mais amplo, que considerou outros concursos do mesmo período, buscando reconhecer o debate da área de arquitetura e urbanismo no âmbito teórico e conceitual e verificando como o paradigma da sustentabilidade urbana e as demandas da precariedade urbana refletem na produção do pensamento arquitetônico. Tendo em vista que distância entre o projeto e obra de urbanização é marcada por inúmeras mudanças ${ }^{1}$ da concepção original, optamos por concentrar a análise no plano das ideias, uma vez que muitas das transformações nem sempre são debatidas entre os autores do projeto original e os gestores responsáveis pelas obras.

Este artigo se organiza nas seguintes sessões: A primeira apresenta os desafios da urbanização de favelas, baseado em pesquisa teórica e fontes secundárias, considerando as dimensões do espaço habitado e do ambiente urbano. O primeiro é composto pelas moradias autoconstruídas, cuja qualidade ambiental é impactada pela alta densidade de ocupação, e pelos conjuntos habitacionais desenhados para a manutenção dos moradores no assentamento, como forma de garantia do direito à moradia e ao lugar. A dimensão urbano-ambiental enfoca os problemas presentes nestes locais, tais como situações de risco pela ocupação de áreas de preservação

'Sobre as mudanças entre projeto e obra, e entre diferentes programas de urbanização de favelas, ver o documentário "Velha Nova Jaguaré", de Maria de Lourdes Zuquim, Yvonne Mautner e Rose Moraes Pan (2013). Disponível em: https://www.youtube.com/watch?v=wnj0RQB0ojs 
permanente, as soluções para o manejo das águas urbanas e para o desenho das áreas verdes.

A segunda sessão apresenta o Concurso Renova SP, o contexto em que foi desenvolvido e as diretrizes formuladas para os temas já mencionados. As terceira e quarta sessões sintetizam, respectivamente, os partidos de projeto para o espaço habitado e para o meio ambiente urbano, cujas soluções são objeto da discussão na sessão final.

\section{Desafios para a habitação e o ambiente urbano dos assentamentos pre-} cários

Assentamentos informais urbanos são áreas ocupadas geralmente por população de baixa renda, cuja gênese é a autoconstrução da moradia e da infraestrutura urbana. O IBGE há décadas contabiliza a população moradora destas localidades, que denomina por "aglomerados subnormais". Estes são descritos como "...forma de ocupação irregular de terrenos de propriedade alheia - públicos ou privados para fins de habitação em áreas urbanas e, em geral, caracterizados por um padrão urbanístico irregular, carência de serviços públicos essenciais e localização em áreas restritas à ocupação" (IBGE, 2019).

Nos países em desenvolvimento, a presença e o crescimento de assentamentos precários nas cidades são marcantes ao longo do século XX. Segundo Villaça (1998, p.226), desde o século XIX o processo de urbanização brasileiro manifesta o rápido crescimento das camadas populares urbanas, quando tem fim o patriarcalismo rural e inicia o processo de industrialização.

Conforme apontado por Oliveira (2003; [1972]), as cidades brasileiras pós 1930 refletem o modelo de desenvolvimento capitalista industrial em que os baixos salários foram o elemento que garantiu a acumulação. Este modelo teve duas repercussões importantes no espaço urbano. Primeiro, impediu o acesso de amplas parcelas populacionais à moradia formal pelo mercado, pois os baixos salários dos operários dificultavam a aquisição deste bem. Segundo, a industrialização brasileira se inseriu de forma periférica no capitalismo internacional, condicionando historicamente (e até os dias de hoje) uma baixa participação do Estado brasileiro quanto aos

${ }^{2}$ Uma recapitulação pormenorizada dos acontecimentos em torno da regulamentação do Estatuto da Cidade foi feita por Maricato (2001, p.96-102) investimentos financeiros necessários à reprodução da vida urbana, como equipamentos urbanos, infraestrutura e a moradia social. Villaça (1998) descreve o processo de estruturação das metrópoles brasileiras como condicionado pela "segregação urbana", em que os recursos estatais são investidos em áreas de interesse das elites urbanas locais, sobretudo dotando-as de infraestruturas de deslocamentos. Aos pobres, resta disputar espaço nas áreas mais baratas e acessíveis, o mais próximo possível da infraestrutura de mobilidade urbana para alcance das oportunidades de emprego e renda.

Maricato (1996) apresentou o crescimento da cidade de São Paulo, em que amplas porções foram ocupadas por moradia precária, em áreas impróprias para uso habitacional como as várzeas de rios e encostas íngremes, situação denominada pela autora como "urbanização com baixos salários" (MARICATO, 2014). Aqui, impera a "exclusão urbanística", pois as favelas "não cabem no contexto do mercado imobiliário formal/legal", estando fora da agenda de planejamento e da gestão urbanos (MARICATO, 2001, p.122). As enormes periferias urbanas formadas ao longo do século XX crescem com base na autoconstrução da casa e da moradia, processo tolerado pelo poder público e ignorado pelas leis e práticas urbanísticas tradicionais. Além a precariedade do espaço urbano e da vulnerabilidade social dos moradores, sofrem cotidianamente os conflitos raciais, de violência urbana e ambientais (MARICATO, 1996), configurando uma "ecologia da desigualdade" (MARICATO, 2001, p.37).

Com a Constituição de 1988 e ampliação dos direitos sociais, as prefeituras são instadas a garantir o atendimento das demandas populares na gestão urbana. Os movimentos sociais urbanos, que levaram o tema da reforma urbana na constituição federal, também atuam localmente, pressionando os municípios a equiparem as periferias desde os anos 1960, quando surgem as primeiras ações de urbanização de favelas em contraposição ao modelo de remoção forçada de assentamentos precários (ANTONUCCl et al, 2017).

A lei $10.257^{2}$ de 2001 regulamenta definitivamente o Estatuto da Cidade, ampliando os instrumentos urbanísticos que as cidades passam a ter para lidar com a questão 
urbana. Dentre eles, a figura das Zonas Especiais de Interesse Social são o principal avanço no que tange às favelas, pois permite regularizar as áreas precárias e informais segundo parâmetros urbanísticos próprios. A partir do Estatuto, as favelas não podem mais ser ignoradas dos mapas e cadastros municipais, devendo integrar as políticas de desenvolvimento urbano para além da política setorial de habitação. Em São Paulo, os sucessivos planos diretores aprovados após o Estatuto das Cidades definem que as ZEIS sejam regularizadas segundo planos de urbanização específicos, aprovados por conselhos gestores das ZEIS, que incluem moradores locais.

Das ações pontuais, os programas de urbanização vêm alargando sua atuação e escopo, além da dotação de infraestrutura básica para intervenções mais amplas (BUENO, 2000; DENALDI, 2003. No caso de São Paulo, o ponto de inflexão se deu na gestão de Luiza Erundina, entre 1989 e $1991^{3}$ (SAMORA, ZUQUIM, 2017), quando a gestão impulsionou distintas linhas de ação para lidar em escala com a variedade de precariedades habitacionais presentes. A conjuntura do PAC Urbanização de Assentamentos Precários em 2007 deu visibilidade e escala para a disseminação de projetos e obras de urbanização por todo o país com recursos federais (CARDOSO, DENALDI, 2018, p. 10-11). Foi neste momento que se deu o concurso Renova SP, objeto deste trabalho.

O conflito entre consolidar as favelas e removê-las, presente desde as primeiras ações, ainda acomete as decisões nos processos de urbanização contemporâneos. O constante adensamento destas áreas dificulta a intervenção, pois o seu crescimento vertical é maior em comparação à expansão territorial, acarretando o aumento da densidade populacional e da área construída (VOSGUERITCHIAN; SAMORA, 2006) tornando as intervenções mais complexas, já que as obras se darão em ambientes previamente ocupados (SAMORA, 2010). A realização das obras de infraestrutura e contenção de risco, bem como o parcelamento dos lotes para regularização da posse demandam significativas remoções, nem sempre atendidas por um número compatível de produção habitacional acessível aos moradores atingidos. Com o advento do programa Minha Casa Minha Vida em 2008, muitos municípios beneficiados pelo PAC usaram este programa para financiar moradia para as famílias, quando estas preenchiam os requisitos deste financiamento. Além disso,

${ }^{3}$ Bueno (2000) e Denaldi (2003) apresentam um histórico das práticas de urbanização de favelas no Brasil; mais recentemente, Samora e Zuquim (2017) retratam a evolução das ações na cidade de é comum a interrupção dos programas e muitas famílias deslocadas permanecerem sem atendimento, ou serem atendidas de forma provisória (conforme os exemplos estudados por Antonucci \& Filocomo, 2017). O risco do programa se extinguir sem ter completado as obras, deixando famílias sem casa, é uma constante no cenário brasileiro. Assim, é consenso que o maior desafio da urbanização de favelas se refere, prioritariamente, à relocação dos moradores atingidos pelas remoções e a garantia do direito à moradia digna (ZUQUIM, 2012; ZUQUIM et al, 2016; PETRAROLLI, 2015; MAZIVIERO, SILVA, 2018; SAMORA, ZUQUIM, 2017; DENALDI, FERRARA, 2018; BRANDAO, BUENO, 2018). Isso explica, em parte, porque muitos programas de urbanização adotaram parâmetros mínimos para consolidar o máximo de moradias, o que termina por impactar a qualidade ambiental destas (SAMORA, 2010).

Outra questão integrante da política de moradia popular se deve às condições de salubridade e a habitabilidade das casas a serem consolidadas pela ação de urbanização. Estas demandam intervenções devido a patologias como situações de insalubridade, estruturais entre outras que impactem sua qualidade, ou necessárias para interligar o domicílio à rede de infraestrutura. Alguns trabalhos discutem a especificidade do tratamento que estas situações demandam (SAMORA, 2010; COELHO, 2017) bem como salientam a importância da participação comunitária nos processos de construção e reconstrução destes espaços (SANTO AMORE, 2016), elementos raramente presente nas políticas de urbanização de favelas.

Vale lembrar que, embora de uso prioritariamente habitacional, o tecido urbano das favelas possui usos comerciais e de serviços. As remoções impactam não só o direito à moradia, mas também os pequenos negócios presentes nas favelas, de onde inúmeras famílias auferem renda (INSTITUTO LOCOMOTIVA, 2020). A importância da relação entre espaços de moradia e geração de renda foi tema da conferência Habitat II (Istambul, 1996), conforme Maricato (2001, p.189). A autora menciona que o financiamento de áreas comerciais junto a moradia social sempre foi impedido pela legislação habitacional brasileira, lacuna ainda nas últimas modalidades de financiamento.

São Paulo, que alternam entre avanços, retrocesso e ambiguidades da intervenção em assentamentos precários e da garantia ao direito à moradia digna. 
Quanto ao aspecto ambiental e urbano, a desigualdade de acesso aos serviços públicos de saneamento básico e infraestrutura são evidentes nos assentamentos precários (FURIGO, 2020) e os moradores são criminalizados por ocupar espaços que deveriam estar preservados (BUENO, 2019; DENALDI, FERRARA, 2018). Em São Paulo, os dados do Plano Municipal de Habitação (PREFEITURA DE SÃO PAULO, 2016) apontavam para 684 assentamentos precários localizados em Áreas de Proteção e Recuperação de Mananciais.

Conforme Bueno (2000) e Denaldi (2003), a "urbanização integrada" é o modelo que não só interfere dentro dos limites da favela, mas integra 0 assentamento à cidade. Tem interface com aspectos mais amplos como as questões de desenvolvimento urbano, ambientais e de drenagem da cidade, o que leva os governos e as agências internacionais a valorizarem soluções integradas para as favelas (DENALDI, 2003).

A ocupação das várzeas por moradias em favelas é enfrentada ao longo das experiências de urbanização, e os corpos d'água foram tratados segundo diferentes concepções. As intervenções da década de 1990/2000 buscavam minimizar as remoções, ao passo que o modelo mais recente propõe a implantação de parques lineares (MISTURA, 2019). Um exemplo é a urbanização da Favela do Sapé, que removeu 1500 das 2500 moradias, com reconstrução no local de 500 novas unidades, financiadas aos moradores, e atendimento de inúmeras famílias em bolsa aluguel (ANTONUCCI, FILOCOMO, 2017; BRANDAO, LEITAO, 2017). Este caso é exemplar quanto à morosidade das intervenções em favelas, tendo em vista que os cadastros de projeto na área começaram em 2011, mas ainda em 2017 a obra continuava incompleta 4 .

A insuficiência de infraestrutura urbana impacta a realidade ambiental das favelas, mas os efeitos desta precariedade não se restringem aos limites físicos destas. Maricato (2001) menciona a importância, para as cidades, de que a da bacia hidrográfica seja a referência para o planejamento e gestão urbanos. $O$ grave déficit de saneamento brasileiro se concentra nas áreas de urbanização precária e só será equacionado com investimentos que priorizem as favelas e loteamentos informais,

${ }^{4} \mathrm{Em}$ visita à área realizada em 2018 com um grupo de estudantes, as lideranças nos relataram que técnicos da prefeitura informavam aos moradores dos novos conjuntos habitacionais que a inadimplência no pagamento do financiamento e das taxas condominiais seria passível de reintegração de dotando-os de redes de coleta e tratamento de esgotos e resíduos sólidos. Isso só é possível a partir de ações intensas de urbanização dos assentamentos precários, mas nem sempre esta visão está presente na visão setorial do saneamento (FURIGO, 2020). Para tanto, é necessário considerar as particularidades destes espaços urbanos quando da expansão destes serviços, de forma a considerá-las na perspectiva da consolidação (FERRARA et al, 2019). Outro aspecto correlato se deve inadequação dos serviços de coleta de resíduos sólidos e às dificuldades geográficas para implantá-los de forma eficiente, tornando as ruas o local de deposição do lixo que se acumula e permanece exposto até ser arrastado em direção aos cursos d'água (FERRARA et al, 2019).

As últimas intervenções em favelas em São Paulo são marcadas pela a abertura de grandes áreas públicas no interior dos assentamentos para a construção de conjuntos habitacionais, em número insuficiente para receber toda a população removida, como visto no Complexo do Jaguaré e Sapé. Além dos desafios da gestão condominial para as famílias de baixa renda, o não equacionamento das remoções e a premência por moradia acarretou a reocupação de vários espaços públicos do Jaguaré, conforme Toi (2017).

Atualmente, os programas de urbanização estão praticamente suspensos no Brasil por falta de recursos federais, desde a crise fiscal que acomete a maioria dos municípios desde 2014 e da aprovação da Emenda Constitucional 95, que congelou os gastos públicos federais por 20 anos e impede a concessão de subsídios diretos vistos na época do PAC (CARDOSO, DENALDI, 2018, p.13)

\section{As diretrizes de projeto no Concurso Renova São Paulo, 2011}

O concurso Renova SP promoveu a elaboração de projetos urbanos na cidade em 2011, e seu edital foi baseado em programas de urbanização de favelas anteriores, que já propunham eliminação das áreas de risco, integração das favelas às redes de infraestrutura urbana e à rotina de manutenção dos serviços públicos e a regularização fundiária. posse, a despeito da grave crise econômica e do desemprego que afeta muitos deles. Informaram
também sobre a descontinuidade do pagamento da bolsa-aluguel, fazendo com que as famílias fossem despejadas. 
O programa de urbanização de favela desenvolvido pela Secretaria Municipal de Habitação da Prefeitura de São Paulo na época do Renova SP tinha como foco "[...] a regularização fundiária de áreas degradas, promovendo acesso a cidade formal aos moradores locais, melhoria das condições de moradia, integração urbana e qualificação socioambiental em conjunto ao desenvolvimento urbano" (Prefeitura de São Paulo ..., 2009). Segundo a Prefeitura, grande parte desses assentamentos ocupavam áreas classificadas como de risco, ou sem regularização fundiária apropriada, entre outras questões.

O Renova SP foi promovido pela Prefeitura, por meio da Secretaria Municipal de Habitação - SEHAB, e do Instituto de Arquitetos do Brasil - IAB e visava a requalificação urbana e habitacional de interesse social em assentamentos precários no município. Os organizadores definiram 22 áreas denominadas de "Perímetros de Ação Integrada - PAl" (que incluíam 82.836 moradias), para os quais solicitaram propostas de Arquitetura e Urbanismo. Posteriormente, foi efetivada a contratação de equipes multidisciplinares, coordenadas pelos arquitetos premiados em primeiro lugar em cada lote, que seriam responsáveis por desenvolver os projetos de urbanização.

As propostas concorrentes deveriam conter soluções para "[...] regularização urbanística e fundiária de áreas territorialmente definidas por meio da ação integrada de qualificação habitacional e urbana, transformando esses assentamentos em áreas integradas à cidade, dotadas de infraestrutura, serviços urbanos e equipamentos comunitários". (PREFEITURA ...,2011.). Os PAls foram definidos segundo bacias hidrográficas, facilitando o planejamento das ações de saneamento. Continham em seu perímetro favelas, loteamentos populares em fase de regularização, terrenos definidos como ZEIS para produção habitacional e conjuntos habitacionais produzidos pelo poder público. Para a pesquisa, selecionamos as diretrizes que impactam os temas da habitação e do meio ambiente urbano, que constavam do edital e guiaram o trabalho das equipes participantes do concurso.

As diretrizes localizavam os perímetros de remoção em cada área e as possibilidades de terrenos vazios para que os participantes desenvolvessem soluções habitacionais para relocação das famílias removidas. O não atendimento às indicações de remoção era passível de desclassificação da proposta, ratificando as áreas consideradas como não consolidáveis no Plano Municipal de Habitação (2016). As diretrizes mencionam que os novos conjuntos habitacionais, quando implantados junto às favelas pré-existentes, deveriam considerar a relação com a vizinhança, demonstrando criatividade e valorização arquitetônica e construtiva, respeito às preexistências e remanejamento de habitações precedido de indicações viáveis de relocação.

Não foram encontradas diretrizes para a melhoria das moradias preexistentes, embora tenham sido propostas por algumas equipes. Outra ausência do edital se deve à menção de outros usos que não os habitacionais, como comércios e serviços, por exemplo.

Quanto à dimensão urbana e ambiental dos projetos, foram formuladas diretrizes mais específicas, estruturadas em consonância com o Plano Municipal de Saneamento Básico de São Paulo, 2011. As diretrizes de macrodrenagem e das áreas de preservação permanente requerem a implantação de pontos de coleta de lixo ao longo dos cursos de água, preferência aos usos paisagísticos ou recreativos nas faixas propícias à inundação e utilização de pavimentação e passeios que permitissem parcialmente a infiltração das águas pluviais.

As diretrizes também requeriam a implantação de pista de circulação de veículos entre os limites dos domicílios e a faixa de preservação dos cursos de água, com acesso para caminhões e outros veículos responsáveis pela coleta de lixo e manutenção das estruturas de drenagem e saneamento básico. Além da consideração quanto aos custos de execução, manutenção e viabilidade técnica, econômica e ambiental das soluções e os aspectos sociais e paisagísticos envolvidos.

Quanto às áreas de risco geotécnico, as diretrizes do edital do Renova SP propõem sua eliminação visando o número mínimo de remoções possíveis e o reassentamento das famílias dentro da área de intervenção. As soluções para remoção seriam definidas pelo projeto de geotecnia e ajustadas pelo projeto de urbanismo proposto.

Para as áreas verdes, o edital indicava que as equipes formulassem soluções para áreas de lazer que atendam a públicos diferentes, com iluminação pública para segurança local. As soluções deveriam preservar e integrar os cursos d'água à paisagem urbana, bem como ampliar áreas verdes com a implantação de parques lineares. Quanto à macrodrenagem, os participantes necessitavam considerar a bacia 
ou sub-bacia hidrográficas como unidade de estudo e planejamento, mesmo que essa ultrapassasse $o$ limite dos assentamentos, considerando a adequação das intervenções aos planos, projetos e obras existentes e previstos. As estruturas de drenagem não poderiam causar impactos nos trechos à jusante de sua implantação e seus custos de execução e manutenção precisavam ser levados em conta. As propostas deviam priorizar a manutenção dos leitos fluviais naturais para evitar o aumentar da velocidade de escoamento das águas. As diretrizes mencionam o conceito de "vazão de restrição" usada para preservar a capacidade de vazão dos canais ao direcionar o aumento do volume das cheias para áreas de estocagem de água, de forma a não afetar as vazões a jusante.

As diretrizes são bastante pormenorizadas quanto às exigências tecnológicas das soluções de saneamento ou os modelos de provisão habitacional, o que contrasta com a pouca relevância dada à demanda por melhoria habitacional e regularização fundiária. A ênfase foi dada aos espaços públicos e aos grandes edifícios habitacionais, exemplificados em obras como a urbanização do Complexo Jaguaré (TOI, 2017, p.178) Estas lacunas permitem antever os conflitos quanto ao direito à moradia, que levou à posterior reocupação dos espaços públicos.

O concurso recebeu e premiou dezessete propostas para as vinte e duas áreas. Apresentamos a seguir a síntese dos principais partidos adotados para as soluções habitacionais e ambientais, para posterior discussão.

\section{O espaço habitado nos projetos premiados}

As propostas quanto ao desenho do espaço habitado foram agrupadas de acordo com partidos de projeto predominantes e resumidas em quadro síntese (Figura 4). Um grupo é composto por edifícios verticalizados de alta densidade, a maioria do tipo lâminas (Figura 1), implantados em terrenos planos, vazios ou onde houve remoções, como ao longo dos córregos. Outro grupo explora as possibilidades de acesso ao edifício num nível intermediário entre o térreo e a cobertura, dispensando o uso de elevadores e aproveitando a topografia de encosta para aumentar a densidade populacional, minimizando movimentação de terra (Figura 2). Outro conjunto de soluções inclui os edifícios com gabaritos mais baixos e próximos daqueles preexistentes no entorno (Figura 3). Flexibilidade e adaptação às necessidades futuras também foram consideradas em duas propostas vencedoras. Há, ainda, a preocupação em minimizar as áreas condominiais e, em alguns casos, usar as novas edificações para criar centralidades e/ou novas frentes e esquinas, valorizando o espaço público e ampliando as possibilidades comerciais.

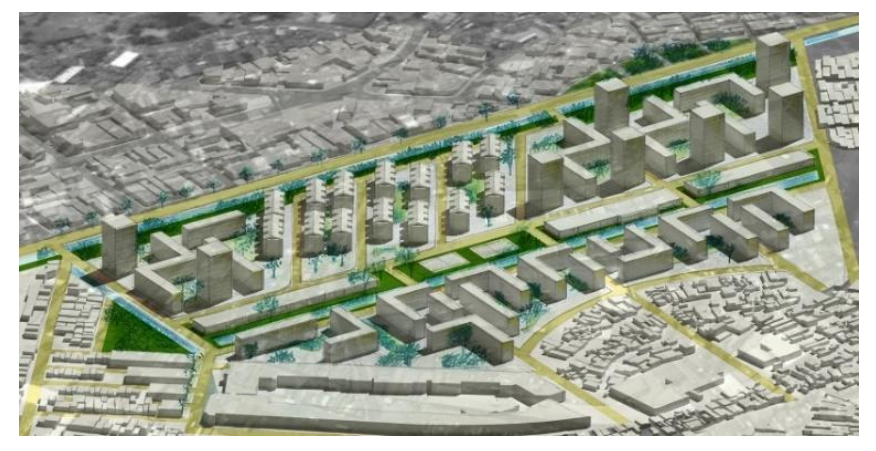

Figura 1: Perímetro 13 - Jardim Japão 1 - Prancha 03, solução de novos edifícios verticalizados em terrenos vazios ou onde houve remoções. Disponível em : https://concursosdeprojeto.files.wordpress.com/2011/08/renova-sp-jardim-japc3a3o-1-1c2ba-lugar-01.jpg. Acesso em: 20 jul. 2020.

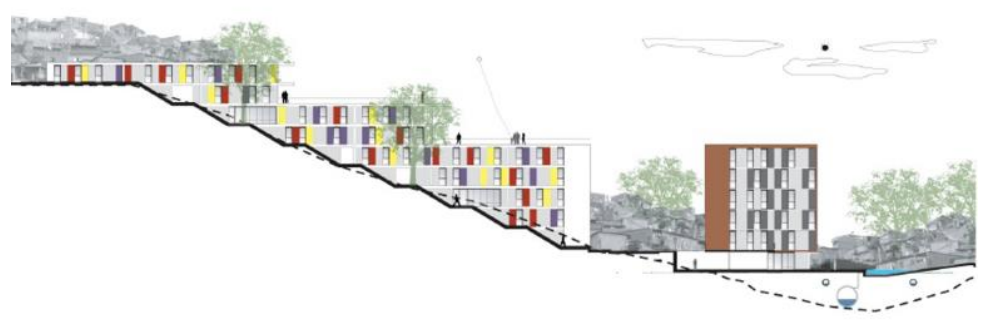

Figura 2: Perímetro 09 - Cabuçu de Baixo 12 - Prancha 2, solução de novas habitações com acesso num nível intermediário. Disponível em : https://concursosdeprojeto.files.wordpress.com/2011/08/prancha2.jpg. Acesso em: 20 jul. 2020.

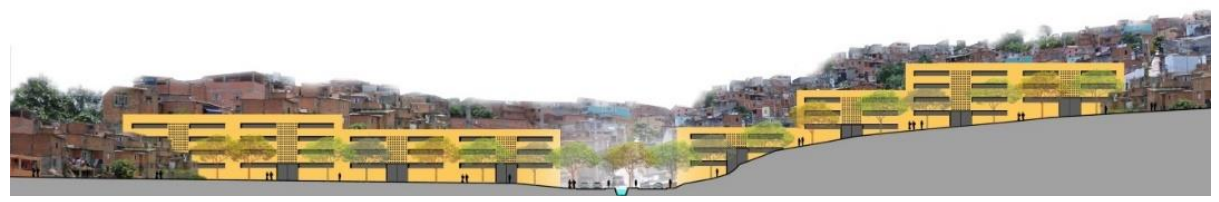

Figura 3: Perímetro 04 - Morro do S4 - Prancha 2, solução de novos edifícios habitacionais com gabaritos mais baixos, próximos ao existente. Disponível em : https://concursosdeprojeto.files.wordpress.com/2011/08/renova-sp-morro-do-s-4-1c2ba-lugar-02.jpg. Acesso em: 20 jul. 2020. 
Como dito, a melhoria das unidades habitacionais não integrava as exigências do edital, porém ao menos 3 equipes formularam estratégias para resolver a insalubridade de moradias em quadras muito densas. Lançam mão de soluções como a revisão das coberturas, garantindo a qualidade de drenagem das águas pluviais, e intervenções no miolo das quadras, promovendo iluminação e ventilação das edificações existentes.

O panorama da figura 4 indica que, caso fossem construídas, a ação de intervenções de grande porte iria prevalecer, com as consequências posteriormente verificadas em Jaguaré e Sapé, que comprometem o direito à moradia e impactam a vida dos moradores.

Nos projetos, está presente o discurso do uso misto e da criação de centralidades, expressas em edifícios plenos de áreas comerciais, mesmo que o programa em questão seja incapaz de implantá-las por limitações de origem e escolha política de atrelar a ação em favelas apenas às linhas de financiamento habitacional vigente. Caso contasse com outro arranjo institucional que garantisse a implantação de áreas comerciais e soluções viáveis para o equacionamento das remoções e regularização fundiária, os problemas relacionados às reocupações das áreas coletivas talvez pudessem ser minimizados. Resta a pergunta sobre às razões da prefeitura de São Paulo em fomentar um modelo de projeto urbano que é inexequível segundo o arranjo das políticas então vigentes.

\section{[Figura 4 na página vertical a seguir.]}

\section{A visão urbano-ambiental nas propostas selecionadas}

De modo geral, os participantes premiados atenderam integralmente às diretrizes urbano-ambientais previstas no edital, como a remoção das moradias em áreas de risco geotécnico e de inundações, com novo desenho para as margens dos córregos. O reassentamento das moradias foi direcionado às novas unidades habitacionais propostas.

Confirmando a tendência apontada por Mistura (2019), os parques lineares foram a solução predominante para as margens dos córregos, que recebem infraestrutura, equipamentos públicos e conjuntos habitacionais nos projetos premiados. São áreas tratadas como transição entre o ecossistema local e o tecido urbano, em que os projetistas advogam por uma cidade peatonal e sob a vigilância dos moradores
(Figura 5). Surgem soluções como "equipamentos de fronteira" e corredores verdes para delimitar as margens a serem preservadas. Visando conter a reocupação destas por novas moradias, os projetos premiados propõem usos coletivos para atrair a comunidade, alguns mencionando a possibilidade de estas abrigarem oportunidades de emprego e geração de renda (Figura 6). Todas as equipes atenderam à diretriz de usar canais abertos.

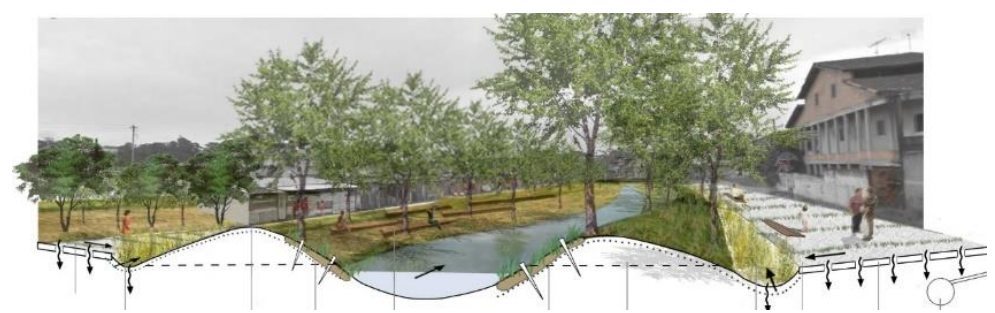

Figura 5: Perímetro 17 - Água Vermelha 02 - Prancha 3, solução de parque linear. Disponível em: https://concursosdeprojeto.org/2011/08/31/concurso-renova-sp-grupo-1-agua-vermelha-201/. Acesso em: 20 jul. 2020.

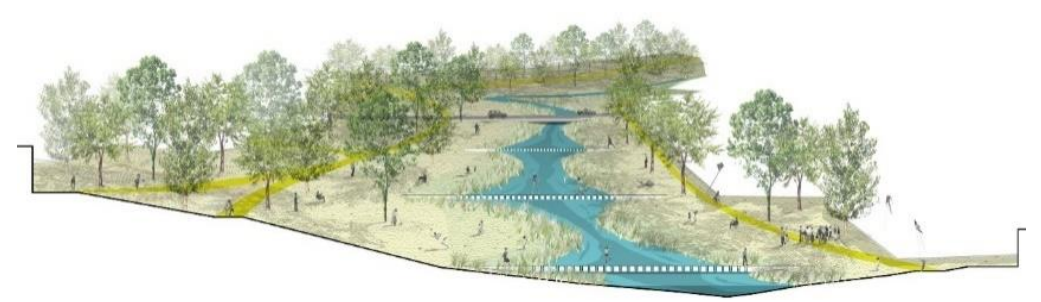

Figura 6: Perímetro 01 - Pirajussara 05 - Prancha 3, solução de equipamentos de fronteira. Disponível em: https://concursosdeprojeto.files.wordpress.com/2011/08/renova-sp-pirajussara-51c2ba-lugar-02.jpg. Acesso em: 20 jul. 2020.

A implantação de vias aliadas a um sistema de áreas verdes e urbanização dos córregos em áreas consolidadas, utilizando o curso d'água como elemento estruturador (Figura 7), foi vista nos projetos Cabuçu de Baixo 5, Pirajussara 5 e Cabuçu de Cima 7. Nas áreas sujeitas a risco geotécnico e inundações sofreram remoções das moradias e seu reassentamento no mesmo local ou em áreas adjacentes. 


\begin{tabular}{|c|c|c|c|c|}
\hline & PAl & Equipes & Novos empreendimentos habitacionais & $\begin{array}{l}\text { Integração e melhoria das unidades } \\
\text { preexistentes }\end{array}$ \\
\hline \multirow{4}{*}{ Grupo 1} & $\begin{array}{l}\text { Água } \\
\text { Verme- } \\
\text { lha } 2\end{array}$ & $\begin{array}{l}\text { Claudio } \\
\text { Libes- } \\
\text { kind }\end{array}$ & $\begin{array}{l}\text { Edifícios em lâminas gerando novos polos de } \\
\text { centralidade através de vazios criados por re- } \\
\text { moções no tecido urbano. }\end{array}$ & - \\
\hline & $\begin{array}{l}\text { Cabuçu } \\
\text { de Baixo } \\
5\end{array}$ & $\begin{array}{l}\text { Rainer } \\
\text { Hehl }\end{array}$ & $\begin{array}{l}\text { Edifícios em lâminas e verticalizados aprovei- } \\
\text { tando encostas para a construção de mais pa- } \\
\text { vimentos sem elevadores e movimentação ex- } \\
\text { cessiva de terra. }\end{array}$ & $\begin{array}{l}\text { Altura dos novos edifícios contrasta com } \\
\text { a pré-existência. }\end{array}$ \\
\hline & $\begin{array}{l}\text { Morro } \\
\text { S4 }\end{array}$ & $\begin{array}{l}\text { Héctor } \\
\text { E. V. } \\
\text { Gani }\end{array}$ & $\begin{array}{l}\text { Edifícios em lâminas acomodados à topogra- } \\
\text { fia local de encosta; reconstrução das bordas } \\
\text { das quadras dando sentido as vias, vielas e } \\
\text { praças públicas, visando à manutenção de } \\
\text { mais famílias. }\end{array}$ & $\begin{array}{l}\text { Gabarito das novas edificações definido a } \\
\text { partir das alturas das edificações preexis- } \\
\text { tentes. }\end{array}$ \\
\hline & $\begin{array}{l}\text { Oratório } \\
1\end{array}$ & $\begin{array}{l}\text { Fábio } R \text {. } \\
\text { Valentim }\end{array}$ & $\begin{array}{l}\text { Edifícios de blocos habitacionais nas cotas } \\
\text { mais altas do terreno, com o acesso direto à } \\
\text { rua. }\end{array}$ & - \\
\hline \multirow{5}{*}{ Grupo 2} & $\begin{array}{l}\text { Ponte } \\
\text { Baixa } 4\end{array}$ & $\begin{array}{l}\text { Daniela } \\
\text { Rama- } \\
\text { Iho }\end{array}$ & $\begin{array}{l}\text { Habitações modulares e flexíveis, adaptáveis } \\
\text { ao longo dos anos, implantadas nas áreas va- } \\
\text { zias e subutilizadas do perímetro de projeto. }\end{array}$ & $\begin{array}{l}\text { Aumento gradativo de pavimentos e al- } \\
\text { tura das novas edificações propostas ao } \\
\text { se afastar das moradias locais. }\end{array}$ \\
\hline & $\begin{array}{l}\text { Pirajus- } \\
\text { sara } 5\end{array}$ & $\begin{array}{l}\text { Libes- } \\
\text { kind- } \\
\text { llovet ar- } \\
\text { quitetos }\end{array}$ & $\begin{array}{l}\text { Edifícios em lâminas, considerando a topogra- } \\
\text { fia local; conexão entre os edifícios realizada } \\
\text { por meio de passarela na cota superior e pelo } \\
\text { acesso ao térreo na cota inferior. }\end{array}$ & $\begin{array}{l}\text { As unidades habitacionais existentes fo- } \\
\text { ram mantidas em sua maioria, sendo re- } \\
\text { movidas as localizadas em áreas de risco } \\
\text { e para qualificação urbana. }\end{array}$ \\
\hline & $\begin{array}{l}\text { Meninos } \\
1\end{array}$ & $\begin{array}{l}\text { Luis } M . \\
\text { Freire }\end{array}$ & $\begin{array}{l}\text { Edifícios em lâminas na extensão do parque } \\
\text { linear proposto, atingindo até } 5 \text { pavimentos. }\end{array}$ & $\begin{array}{l}\text { Novas edificações não contrastam e se } \\
\text { integram às edificações do entorno. }\end{array}$ \\
\hline & $\begin{array}{l}\text { Jardim } \\
\text { Japão } 1\end{array}$ & $\begin{array}{l}\text { Paulo E. } \\
\text { B. Fer- } \\
\text { reira }\end{array}$ & $\begin{array}{l}\text { Edifícios em lâminas e verticalizados voltados } \\
\text { ao passeio público, fundindo os tecidos adja- } \\
\text { centes com a inserção de novos usos e ampli- } \\
\text { ação das áreas livres comuns. }\end{array}$ & $\begin{array}{l}\text { Qualificação de conjuntos habitacionais } \\
\text { existentes no perímetro e melhoria das } \\
\text { unidades habitacionais existentes através } \\
\text { da revisão das coberturas garantindo a } \\
\text { qualidade de drenagem das águas pluvi- } \\
\text { ais. }\end{array}$ \\
\hline & $\begin{array}{l}\text { Cabuçu } \\
\text { de Cima } \\
8\end{array}$ & $\begin{array}{l}\text { Eduardo } \\
\text { Ferroni }\end{array}$ & $\begin{array}{l}\text { Edifícios em lâminas nas encostas e com au- } \\
\text { mento da densidade populacional, já que o nú- } \\
\text { mero de unidades criadas é superior ao de } \\
\text { unidades removidas. }\end{array}$ & $\begin{array}{l}\text { Novas edificações não atingem elevadas } \\
\text { alturas e dimensões, integrando-se com } \\
\text { as edificações do entorno. }\end{array}$ \\
\hline \multirow{3}{*}{ Grupo 3} & $\begin{array}{l}\text { Cabuçu } \\
\text { de Cima } \\
10\end{array}$ & $\begin{array}{l}\text { Base 3 } \\
\text { Arquite- } \\
\text { tos }\end{array}$ & $\begin{array}{l}\text { Edifícios em lâminas e blocos verticalizados } \\
\text { com acesso por elevadores. }\end{array}$ & $\begin{array}{l}\text { Os novos edifícios destacam-se das edifi- } \\
\text { cações do entorno. }\end{array}$ \\
\hline & $\begin{array}{l}\text { Cabuçu } \\
\text { de Baixo } \\
12\end{array}$ & $\begin{array}{l}\text { Monica } \\
\text { Drucker }\end{array}$ & $\begin{array}{l}\text { Edifícios em lâminas e blocos na extensão do } \\
\text { parque linear proposto, com acesso a partir do } \\
\text { desnível local, permitindo a construção de } \\
\text { mais pavimentos sem a necessidade de ele- } \\
\text { vadores. }\end{array}$ & $\begin{array}{l}\text { Intervenções no miolo das quadras pro- } \\
\text { movendo iluminação e ventilação das edi- } \\
\text { ficações existentes. }\end{array}$ \\
\hline & $\begin{array}{l}\text { Cabuçu } \\
\text { de Baixo } \\
4\end{array}$ & $\begin{array}{l}\text { Paulo E. } \\
\text { B. Fer- } \\
\text { reira }\end{array}$ & $\begin{array}{l}\text { Edifícios em lâminas e verticalizados nos va- } \\
\text { zios gerados a partir de remoções de mora- } \\
\text { dias nos miolos de quadra. }\end{array}$ & $\begin{array}{l}\text { Melhoria das unidades habitacionais exis- } \\
\text { tentes com uso de telhados e criação de } \\
\text { espaços públicos no interior das quadras. }\end{array}$ \\
\hline \multirow{5}{*}{ Grupo 4} & $\begin{array}{l}\text { Tiquatira } \\
2\end{array}$ & $\begin{array}{l}\text { Virginia } \\
\text { Murad }\end{array}$ & $\begin{array}{l}\text { Edifícios em lâminas com } 2 \text { tipologias: so- } \\
\text { brado e apartamento duplex. }\end{array}$ & $\begin{array}{l}\text { Manutenção do maior número de edifica- } \\
\text { ções existentes na área, preservando os } \\
\text { vínculos sociais estabelecidos. }\end{array}$ \\
\hline & $\begin{array}{l}\text { Pirajus- } \\
\text { sara } 7\end{array}$ & $\begin{array}{l}\text { Patricia } \\
\text { G. Padi- } \\
\text { lha }\end{array}$ & $\begin{array}{l}\text { Habitações modulares, flexíveis e verticaliza- } \\
\text { das. }\end{array}$ & - \\
\hline & $\begin{array}{l}\text { Cordeiro } \\
1\end{array}$ & $\begin{array}{l}\text { Carolina } \\
\text { H. Cer- } \\
\text { vellini }\end{array}$ & - & $\begin{array}{l}\text { Requalificação das unidades habitacio- } \\
\text { nais de assentamentos com alto grau de } \\
\text { consolidação e integração com o entorno. }\end{array}$ \\
\hline & $\begin{array}{l}\text { Cabuçu } \\
\text { de Cima } \\
7\end{array}$ & $\begin{array}{l}\text { Pedro } \\
\text { Tuma }\end{array}$ & $\begin{array}{l}\text { Edifícios em lâminas na extensão do parque } \\
\text { linear proposto, com até } 5 \text { pavimentos, bus- } \\
\text { cando aproveitamento da topografia local de } \\
\text { encosta para acessos. }\end{array}$ & $\begin{array}{l}\text { Novas edificações não atingem elevadas } \\
\text { alturas e dimensões, integrando-se com } \\
\text { as edificações do entorno. }\end{array}$ \\
\hline & $\begin{array}{l}\text { Água } \\
\text { Esprai- } \\
\text { ada } 2 \text { e } \\
5\end{array}$ & $\begin{array}{l}\text { Paulo J. } \\
\text { V. Bruna }\end{array}$ & $\begin{array}{l}\text { Edifícios em lâminas com até } 5 \text { pavimentos, } \\
\text { buscando aproveitamento da topografia local } \\
\text { de encosta. }\end{array}$ & $\begin{array}{l}\text { Requalificação das unidades habitacio- } \\
\text { nais consolidadas e que não estão em } \\
\text { área de risco, mantendo o maior número } \\
\text { possível de edificações pré-existentes. }\end{array}$ \\
\hline
\end{tabular}

Figura 4: Quadro síntese das soluções habitacionais propostas, por grupo e área (PAl). Fonte: Elaboração própria com base nas propostas premiadas pelo Renova SP, 2011 


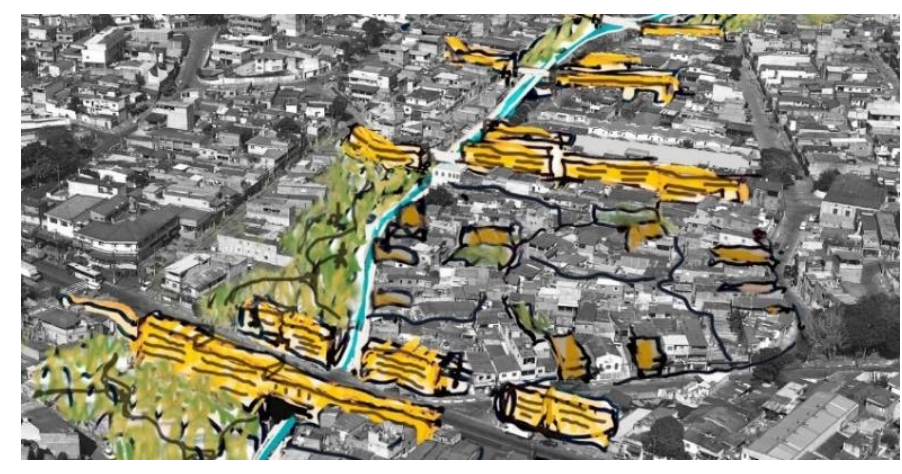

Figura 7: Perímetro 04 - Morro do S4 - Prancha 2, solução do curso d'água como elemento estruturador. Disponível em : https://concursosdeprojeto.org/2011/08/31/concurso-renova-sp-grupo1-morro-do-s-4-01/. Acesso em: 20 jul. 2020.

Para controlar a vazão de pico e a velocidade de escoamento das águas pluviais, as equipes seguiram as diretrizes de implantação de zona de amortecimento (tipo bacias de retenção e detenção), e outros elementos como açudes e jardins de chuva, ocupando áreas liberadas pelas remoções.

Alguns projetos lembram que as melhorias de saneamento exigem a ligação das unidades existentes às redes, e indicam a necessidade de se prever assessoria técnica às famílias para estas intervenções arquitetônicas e estruturais. Em alguns casos, a interface entre a moradia e o sistema público de esgoto demanda a reestruturação do sistema viário e o redesenho do miolo de quadra. São propostas aberturas de vazios que recebem praças, elementos de contenção de drenagem e conexões das unidades às redes de esgoto e drenagem das águas pluviais. Outra preocupação verificada no Oratório 1 se refere ao cadastro da rede de esgoto e interligação dos domicílios aos coletores existentes no entorno. Uma equipe (Cabuçu de Cima 8) propôs o uso dos terrenos sob as linhas de alta tensão, para implantação de hortas urbanas.

As soluções condensadas na figura 8 refletem o entendimento do modelo de urbanização de favelas como um grande projeto urbano, em que a escala da moradia se torna difusa frente à da bacia e da macro drenagem. Os espaços públicos projetados levam muito mais a uma apropriação pela escala metropolitana do que são desenhados para as necessidades cotidianas. Ainda assim, algumas propostas buscaram recolocar necessidades prementes das favelas quanto ao reordenamento dos miolos de quadra, não por um discurso meramente estético, mas como condição básica para o funcionamento da rede de esgoto, assunto ignorado nas diretrizes do edital.

\section{[Figura 8 na página vertical a seguir]}

\section{Discussão}

O fato de cinco das vinte e duas áreas inicialmente previstas não terem recebido propostas demonstra a abrangência e complexidade do Renova SP, exemplo de concurso fortemente direcionado, tendo em vista a quantidade e pormenorização das diretrizes formuladas. Além disso, aceitar o parâmetro imposto de remoção de moradias, ainda que em alguns casos não houvesse risco evidente que impedisse a consolidação de muitas casas, era condição para a participação no certame. Caso todas as obras de urbanização previstas na totalidade dos perímetros tivessem sido efetivadas nos anos posteriores, certamente o impacto em termos de escala das remoções e transformação urbana seria notável.

Como dito, as soluções premiadas alteram de forma significativa a morfologia da área de intervenção. A remoção das moradias se deve à abertura de vias, redesenho das margens de córregos, implantação de áreas verdes e equipamentos de lazer, ou para dotar os miolos de quadra de praças, elementos de contenção de drenagem e redes de saneamento. Em que pese as determinações do edital, os arquitetos acabam por deixar prevalecer em suas propostas um olhar destinado as favelas como uma questão da cidade e do urbanismo, passível de ser solucionado a partir de um saber técnico, menosprezando os impactos deste modelo na vida dos moradores removidos.

No âmbito das propostas habitacionais, cabe indagar por que os organizadores não formularam diretrizes para melhorias no espaço habitado. Ainda assim, algumas equipes demonstraram estar atentas a esta necessidade, não apenas por questões de segurança e salubridade das moradias autoconstruídas, mas porque a habitação é a primeira unidade de planejamento das infraestruturas urbanas. 


\begin{tabular}{|c|c|c|c|c|c|c|}
\hline & PAI & Equipes & $\begin{array}{l}\text { Saneamento e Manejo } \\
\text { das águas urbanas }\end{array}$ & $\begin{array}{l}\text { Áreas de risco geo- } \\
\text { técnico e inunda- } \\
\text { ções }\end{array}$ & Áreas verdes & $\begin{array}{l}\text { Macrodrena- } \\
\text { gem }\end{array}$ \\
\hline \multirow{4}{*}{ Grupo 1} & $\begin{array}{l}\text { Água } \\
\text { Verme- } \\
\text { Iha } 2\end{array}$ & $\begin{array}{l}\text { Claudio } \\
\text { Libes- } \\
\text { kind }\end{array}$ & $\begin{array}{l}\text { Recuperação dos açudes } \\
\text { existentes, abertura de } \\
\text { ruas, recolhimento das } \\
\text { águas pluviais e encami- } \\
\text { nhamento aos açudes } \\
\text { para o processo de fito } \\
\text { depuração e implantação } \\
\text { de coleta de esgoto }\end{array}$ & $\begin{array}{l}\text { Controle das inunda- } \\
\text { ções por represa de } \\
\text { contenção das águas } \\
\text { pluviais; remoção das } \\
\text { unidades em áreas de } \\
\text { risco e realocação dos } \\
\text { moradores na própria } \\
\text { área }\end{array}$ & $\begin{array}{l}\text { Implantação de um } \\
\text { Parque Linear ao } \\
\text { longo do córrego e } \\
\text { potencialização do } \\
\text { corredor verde fluvial }\end{array}$ & $\begin{array}{l}\text { Uso de solu- } \\
\text { ções a céu } \\
\text { aberto, vi- } \\
\text { sando a inte- } \\
\text { gração com } \\
\text { entorno e fa- } \\
\text { cilidade de } \\
\text { manutenção }\end{array}$ \\
\hline & $\begin{array}{l}\text { Cabuçu } \\
\text { de Baixo } \\
5\end{array}$ & $\begin{array}{l}\text { Rainer } \\
\text { Hehl }\end{array}$ & $\begin{array}{l}\text { Sistema viário principal } \\
\text { aliado aos espaços ver- } \\
\text { des, reestruturação das } \\
\text { vias e dos miolos de qua- } \\
\text { dras para a implantação } \\
\text { de redes de drenagem, } \\
\text { unidades habitacionais e } \\
\text { equipamentos públicos }\end{array}$ & $\begin{array}{l}\text { Medidas contra desli- } \\
\text { zamentos de terra e } \\
\text { inundações; remoção } \\
\text { das unidades em risco } \\
\text { localizadas nas en- } \\
\text { costas e remaneja- } \\
\text { mento habitacional } \\
\text { nos novos conjuntos }\end{array}$ & $\begin{array}{l}\text { Melhoria do córrego e } \\
\text { criação de um parque } \\
\text { linear, de novos equi- } \\
\text { pamentos de fronteira } \\
\text { e de um parque pú- } \\
\text { blico na área onde } \\
\text { havia depósito de lixo } \\
\text { irregular }\end{array}$ & $\begin{array}{l}\text { Uso de solu- } \\
\text { ções a céu } \\
\text { aberto, vi- } \\
\text { sando a inte- } \\
\text { gração com } \\
\text { entorno e fa- } \\
\text { cilidade de } \\
\text { manutenção }\end{array}$ \\
\hline & $\begin{array}{l}\text { Morro } \\
\text { S4 }\end{array}$ & $\begin{array}{l}\text { Héctor } \\
\text { E. V. V. } \\
\text { Gani }\end{array}$ & - & $\begin{array}{l}\text { Remoções das unida- } \\
\text { des habitacionais nas } \\
\text { áreas de riscos e re- } \\
\text { assentamento dos do- } \\
\text { micílios removidos } \\
\text { nas unidades habita- } \\
\text { cionais propostas } \\
\text { para o local }\end{array}$ & $\begin{array}{l}\text { Implantação de um } \\
\text { parque linear e de } \\
\text { bolsões verdes junto } \\
\text { às pontes urbanas } \\
\text { com equipamento de } \\
\text { lazer e de infraestru- } \\
\text { tura na avenida inte- } \\
\text { grada ao córrego com } \\
\text { passeios, ciclovia e } \\
\text { iluminação pública }\end{array}$ & $\begin{array}{l}\text { Uso de solu- } \\
\text { ções a céu } \\
\text { aberto, vi- } \\
\text { sando a inte- } \\
\text { gração com } \\
\text { entorno e fa- } \\
\text { cilidade de } \\
\text { manutenção }\end{array}$ \\
\hline & $\begin{array}{l}\text { Oratório } \\
1\end{array}$ & $\begin{array}{l}\text { Fábio R. } \\
\text { Valentim }\end{array}$ & $\begin{array}{l}\text { Catalogação da rede de } \\
\text { esgoto dos domicílios, } \\
\text { promovendo a interliga- } \\
\text { ção aos troncos coletores } \\
\text { existentes }\end{array}$ & $\begin{array}{l}\text { Retardamento das } \\
\text { águas pluviais e re- } \\
\text { moções das famílias } \\
\text { em áreas de riscos e } \\
\text { realocação em áreas } \\
\text { adjacentes }\end{array}$ & $\begin{array}{l}\text { Implantação de um } \\
\text { parque linear e arbo- } \\
\text { rização das nascen- } \\
\text { tes dos rios }\end{array}$ & $\begin{array}{l}\text { Uso de solu- } \\
\text { ções a céu } \\
\text { aberto }\end{array}$ \\
\hline \multirow{5}{*}{ Grupo 2} & $\begin{array}{l}\text { Ponte } \\
\text { Baixa } 4\end{array}$ & $\begin{array}{l}\text { Daniela } \\
\text { Rama- } \\
\text { Iho }\end{array}$ & - & $\begin{array}{l}\text { Remoção das famílias } \\
\text { em áreas de risco e } \\
\text { realocação em novas } \\
\text { unidades habitacio- } \\
\text { nais na área }\end{array}$ & $\begin{array}{l}\text { Implantação de um } \\
\text { parque Linear e urba- } \\
\text { nização do Parque } \\
\text { existente Produtivo } \\
\text { Agrícola }\end{array}$ & $\begin{array}{l}\text { Uso de solu- } \\
\text { ções a céu } \\
\text { aberto }\end{array}$ \\
\hline & $\begin{array}{l}\text { Pirajus- } \\
\text { sara } 5\end{array}$ & $\begin{array}{l}\text { Libes- } \\
\text { kind- } \\
\text { llovet ar- } \\
\text { quitetos }\end{array}$ & $\begin{array}{l}\text { Revitalização dos espa- } \\
\text { ços públicos, implanta- } \\
\text { ção de rede de esgoto se- } \\
\text { paradas para águas de } \\
\text { reuso e esgoto }\end{array}$ & $\begin{array}{l}\text { Remoção dos assen- } \\
\text { tamentos em encos- } \\
\text { tas, implementação } \\
\text { de açudes e de bacia } \\
\text { de retenção e realoca- } \\
\text { ção dos moradores na } \\
\text { área }\end{array}$ & $\begin{array}{l}\text { Implantação de um } \\
\text { parque linear e de um } \\
\text { anel verde com equi- } \\
\text { pamentos de lazer e } \\
\text { utilização da bioenge- } \\
\text { nharia }\end{array}$ & $\begin{array}{l}\text { Córrego } \\
\text { como eixo es- } \\
\text { truturador e } \\
\text { preferência } \\
\text { as soluções a } \\
\text { céu aberto }\end{array}$ \\
\hline & $\begin{array}{l}\text { Meninos } \\
1\end{array}$ & $\begin{array}{l}\text { Luis } M . \\
\text { Freire }\end{array}$ & - & $\begin{array}{l}\text { Remoção da favela ao } \\
\text { longo do córrego e re- } \\
\text { alocação no entorno } \\
\text { do parque }\end{array}$ & $\begin{array}{l}\text { Implantação de um } \\
\text { parque linear ao } \\
\text { longo do córrego com } \\
\text { vias conectando as } \\
\text { margens do rio }\end{array}$ & $\begin{array}{l}\text { Retificação } \\
\text { do rio ampli- } \\
\text { ando a Faixa } \\
\text { de APP e ca- } \\
\text { nalização rio } \\
\text { para a cria- } \\
\text { ção de praça } \\
\text { pública }\end{array}$ \\
\hline & $\begin{array}{l}\text { Jardim } \\
\text { Japão } 1\end{array}$ & $\begin{array}{l}\text { Paulo E. } \\
\text { B. Fer- } \\
\text { reira }\end{array}$ & $\begin{array}{l}\text { Implantação de rede for- } \\
\text { mal de saneamento a to- } \\
\text { das unidades habitacio- } \\
\text { nais e de sistema de dre- } \\
\text { nagem urbana e macro- } \\
\text { drenagem. Melhoria das } \\
\text { coberturas das moradias } \\
\text { para coleta da água de } \\
\text { chuva }\end{array}$ & $\begin{array}{l}\text { Remoção das unida- } \\
\text { des habitacionais nas } \\
\text { áreas de risco e rema- } \\
\text { nejamento no interior } \\
\text { da área }\end{array}$ & $\begin{array}{l}\text { Sistema de áreas li- } \\
\text { vres aliado aos cur- } \\
\text { sos d'água a serem } \\
\text { recuperados, com } \\
\text { equipamentos públi- } \\
\text { cos e integração en- } \\
\text { tre as duas margens } \\
\text { do Córrego }\end{array}$ & - \\
\hline & $\begin{array}{l}\text { Cabuçu } \\
\text { de Cima } \\
8\end{array}$ & $\begin{array}{l}\text { Eduardo } \\
\text { Ferroni }\end{array}$ & $\begin{array}{l}\text { Recuperação de curso } \\
\text { d'água, instalação de co- } \\
\text { letores-tronco, criação de } \\
\text { centralidades e espaços } \\
\text { públicos de escala regio- } \\
\text { nal }\end{array}$ & $\begin{array}{l}\text { Remoção dos mora- } \\
\text { dores em área de } \\
\text { risco e realocação na } \\
\text { área }\end{array}$ & $\begin{array}{l}\text { Implantação de um } \\
\text { parque linear e de } \\
\text { hortas urbanas sob } \\
\text { as linhas de alta ten- } \\
\text { são e recuperação de } \\
\text { encostas, dos córre- } \\
\text { gos e nascentes }\end{array}$ & $\begin{array}{l}\text { Uso de solu- } \\
\text { ções a céu } \\
\text { aberto, vi- } \\
\text { sando a inte- } \\
\text { gração com } \\
\text { entorno e fa- } \\
\text { cilidade de } \\
\text { manutenção }\end{array}$ \\
\hline Grupo 3 & $\begin{array}{l}\text { Cabuçu } \\
\text { de Cima } \\
10\end{array}$ & $\begin{array}{l}\text { Base } 3 \\
\text { Arquite- } \\
\text { tos }\end{array}$ & - & $\begin{array}{l}\text { Remoção dos mora- } \\
\text { dores em área de } \\
\text { risco e realocação no } \\
\text { entorno do parque }\end{array}$ & $\begin{array}{l}\text { Implantação de um } \\
\text { parque linear, conti- } \\
\text { nuidade das áreas } \\
\text { verdes e integração } \\
\text { entre as margens do } \\
\text { rio }\end{array}$ & $\begin{array}{l}\text { Uso de solu- } \\
\text { ções a céu } \\
\text { aberto }\end{array}$ \\
\hline
\end{tabular}


Luana Diana e Patrícia Rodrigues Samora

\begin{tabular}{|c|c|c|c|c|c|c|}
\hline & $\begin{array}{l}\text { Cabuçu } \\
\text { de Baixo } \\
12\end{array}$ & $\begin{array}{l}\text { Monica } \\
\text { Drucker }\end{array}$ & - & $\begin{array}{l}\text { Remoções das unida- } \\
\text { des habitacionais nas } \\
\text { áreas de riscos e rea- } \\
\text { locação na área }\end{array}$ & $\begin{array}{l}\text { Implantação de um } \\
\text { parque linear e de } \\
\text { praças nos miolos de } \\
\text { quadra }\end{array}$ & $\begin{array}{l}\text { Uso de solu- } \\
\text { ções a céu } \\
\text { aberto }\end{array}$ \\
\hline & $\begin{array}{l}\text { Cabuçu } \\
\text { de Baixo } \\
4\end{array}$ & $\begin{array}{l}\text { Paulo E. } \\
\text { B. Fer- } \\
\text { reira }\end{array}$ & $\begin{array}{l}\text { Contenção e drenagem } \\
\text { superficial e ligação de } \\
\text { das unidades ao sanea- } \\
\text { mento básico e assesso- } \\
\text { ria técnica as famílias em } \\
\text { intervenções e melhoria } \\
\text { das coberturas das mora- } \\
\text { dias para coleta da água } \\
\text { de chuva }\end{array}$ & $\begin{array}{l}\text { Remoção das mora- } \\
\text { dias em áreas de } \\
\text { risco, contenção de } \\
\text { encostas, implanta- } \\
\text { ção de escadaria hi- } \\
\text { dráulica, tanques de } \\
\text { retenção e absorção e } \\
\text { reassentamento das } \\
\text { famílias na área }\end{array}$ & $\begin{array}{l}\text { Implantação de um } \\
\text { parque linear e de } \\
\text { "equipamentos } \\
\text { fronteira" }\end{array}$ & $\begin{array}{l}\text { Uso de solu- } \\
\text { ções a céu } \\
\text { aberto, vi- } \\
\text { sando a inte- } \\
\text { gração com } \\
\text { entorno e fa- } \\
\text { cilidade de } \\
\text { manutenção }\end{array}$ \\
\hline \multirow{5}{*}{ Grupo 4} & $\begin{array}{l}\text { Tiquatira } \\
2\end{array}$ & $\begin{array}{l}\text { Virginia } \\
\text { Murad }\end{array}$ & (1) & $\begin{array}{l}\text { Remoção do menor } \\
\text { número de edifica- } \\
\text { ções e reassenta- } \\
\text { mento na área ou no } \\
\text { perímetro }\end{array}$ & $\begin{array}{l}\text { Implantação de um } \\
\text { parque linear }\end{array}$ & - \\
\hline & $\begin{array}{l}\text { Pirajus- } \\
\text { sara } 7\end{array}$ & $\begin{array}{l}\text { Patricia } \\
\text { G. Padi- } \\
\text { lha }\end{array}$ & - & - & $\begin{array}{l}\text { Implantação de áreas } \\
\text { verdes e equipamen- } \\
\text { tos públicos e desocu- } \\
\text { pação dos espaços } \\
\text { hídricos }\end{array}$ & - \\
\hline & $\begin{array}{l}\text { Cordeiro } \\
1\end{array}$ & $\begin{array}{l}\text { Carolina } \\
\text { H. Cer- } \\
\text { vellini }\end{array}$ & - & $\begin{array}{l}\text { Zona de amortização } \\
\text { do volume de água de } \\
\text { tormentas, através da } \\
\text { estação de fito depu- } \\
\text { ração e de } 3 \text { jardins de } \\
\text { chuva }\end{array}$ & $\begin{array}{l}\text { Implantação de um } \\
\text { parque linear e um } \\
\text { corredor verde }\end{array}$ & $\begin{array}{l}\text { Instalação de } \\
\text { fito remedia- } \\
\text { ção por meio } \\
\text { do uso de } \\
\text { plantas }\end{array}$ \\
\hline & $\begin{array}{l}\text { Cabuçu } \\
\text { de Cima } \\
7\end{array}$ & $\begin{array}{l}\text { Pedro } \\
\text { Tuma }\end{array}$ & $\begin{array}{l}\text { Urbanização dos córre- } \\
\text { gos em faixas urbanas } \\
\text { consolidadas e utilização } \\
\text { do curso d'agua como } \\
\text { eixo estruturador }\end{array}$ & $\begin{array}{l}\text { Remoção das mora- } \\
\text { dias em áreas de risco } \\
\text { para a contenção geo- } \\
\text { técnica e refloresta- } \\
\text { mento e realocação } \\
\text { em novas habitações } \\
\text { na borda do parque }\end{array}$ & $\begin{array}{l}\text { Implantação de um } \\
\text { parque linear na área } \\
\text { subutilizada do cemi- } \\
\text { tério }\end{array}$ & $\begin{array}{l}\text { Implantação } \\
\text { de praça } \\
\text { d'água com } \\
\text { uma bacia de } \\
\text { retenção das } \\
\text { águas pluvi- } \\
\text { ais }\end{array}$ \\
\hline & $\begin{array}{l}\text { Água } \\
\text { Esprai- } \\
\text { ada } 2 \text { e } 5\end{array}$ & $\begin{array}{l}\text { Paulo J. } \\
\text { V. Bruna }\end{array}$ & - & $\begin{array}{l}\text { Remoção das mora- } \\
\text { dias em áreas de risco } \\
\text { e realocação dos mo- } \\
\text { radores na área }\end{array}$ & $\begin{array}{l}\text { Implantação de um } \\
\text { parque linear }\end{array}$ & - \\
\hline
\end{tabular}

Figura 8: Quadro das soluções ambientais premiadas, por grupo e área (PAI). Fonte: Elaboração própria com base nas propostas premiadas pelo Renova SP, 2011. 
Do ponto de vista da gestão das águas urbanas, é inconcebível a implantação das redes de esgotamento sanitário sem a interligação das unidades nesta. Para tanto, se fazem necessários ajustes nas conexões e até implantação de unidades sanitárias para perfeito funcionamento do sistema. Da mesma forma, embora o discurso do tratamento ecológico das águas de chuva tenha sido valorizado nas e nos projetos premiados, a questão da micro drenagem depende em algum grau de ajustes intra-lotes. Esta foi abordada pelas equipes que se preocuparam com a drenagem interna aos lotes a partir da instalação de coberturas, calhas e dutos para então serem destinadas às redes de águas pluviais.

Tendo em vista esta ausência quanto aos problemas a serem enfrentados em urbanização de favelas no que diz respeito à pequena escala, pode-se afirmar que a produção do Renova SP, salvo as exceções mencionadas, aborda a questão habitacional como algo afeto à grande escala, a partir de ampla remoção e redesenho de grandes conjuntos inseridos nos assentamentos. A partir disso, a discussão é quanto ao modelo mais eficiente para abrigar o contingente de famílias removidas.

A produção do Renova SP para a escala urbano-ambiental apresenta um discurso bastante forte quanto ao manejo das águas da chuva, abordado a partir das peculiaridades de cada sub-bacia e atendendo a diretrizes pré-definidas para a adoção de bacias de detenção provisória de águas pluviais. Sem dúvida, o grau de impermeabilização da cidade de São Paulo, sobretudo nos espaços periféricos, aumenta o risco de inundações. Conter as águas durante a vazão de pico, diminuir sua velocidade de escoamento e permitir que estas infiltrem onde ocorre as chuvas são estratégias usadas por cidades no mundo todo, com resultados que mitigam os impactos da urbanização, diminuem a vulnerabilidade e melhoram a qualidade dos corpos d'água.

No mesmo sentido, os parques lineares foram o desenho ambiental predominante nas áreas junto à córregos, e indicam que, embora ainda sejam a solução predominante nas obras públicas das cidades, ao menos na visão dos arquitetos e urbanistas as "avenidas de fundos de vale" não são consideradas. Os córregos, que nas ocupações originais estão sob as casas mais precárias, são reabertos. Suas margens são redesenhadas e recebem espaços de circulação não motorizada e de lazer. Junto com as soluções de drenagem já mencionadas, esta visão urbana, de resgate da natureza na cidade e reaproximação do cidadão com as águas é o modelo urbanístico que atualmente anima as discussões contemporâneas da Arquitetura e do Urbanismo.

\section{Conclusões}

A visão conjunta das dezessete propostas premiadas revela uma intenção de amplo redesenho das áreas precárias. $O$ impacto quanto ao número de remoções é resposta direta às diretrizes do edital e condescendência dos participantes. Neste modelo, a remoção de moradias estaria atrelada à uma visão de política habitacional mais calcada na produção e ampliação do estoque habitacional que, como mencionado, era financiado pelo programa Minha Casa Minha Vida.

Se este é o único ou o melhor caminho para as favelas brasileiras em áreas urbanas, questões importantes ainda permanecem: Quem será removido para dar lugar a esta ideia de cidade? Como as famílias removidas são atendidas, tendo em vista o histórico de incompletude destas políticas?

Os projetos premiados enfrentaram o desafio colocado, constituindo mais um ensaio pela ótica predominante da Arquitetura e do Urbanismo contemporâneos, utilizando suas ferramentas. Porém, são experiências fruto de uma política pública hierárquica, formulada de cima para baixo, bastante técnica e bem pouco popular.

Nesta lógica de entendimento, ações produzidas no âmbito de uma política habitacional mais restrita, construída a partir do diálogo com os moradores, que busca soluções de menor impacto, não cabem. O "grande projeto urbano", no entanto, deve ser visto com cuidado, sobretudo quando aplicado em espaços de moradia popular. Sabe-se que em inúmeras situações o direito à moradia digna e à permanência são violados pela própria política habitacional local. Esperamos que, quando o país se voltar às periferias precárias para cumprimento dos deveres constitucionais, o silêncio ensurdecedor dos moradores não poderá mais ser tolerado na concepção e implementação das futuras intervenções em assentamentos precários urbanos.

\section{Agradecimentos}

As autoras agradecem à Pontifícia Universidade Católica de Campinas pela bolsa de iniciação científica para o desenvolvimento desta pesquisa. 


\section{Referências bibliográficas}

ANTONUCCI, D,; FILOCOMO, G. Provisão habitacional em assentamentos precários. Jaguaré e Sapé. In:ZUQUIM, M.L; SANCHEZ-MAZO, L. Barrios populares Medellín: favelas São Paulo.1a ed. São Paulo: FAUUSP, 2017, v.1, p. 260-270.

ANTONUCCI, D.; PRESTES, M. F.; SAMORA, P. R.; ZUQUIM, M.L. Da luta pela moradia à urbanização de assentamentos precários: a política habitacional no Brasil. In: ZUQUIM, M.L; SANCHEZ-MAZO, L. Barrios populares Medellín: favelas São Paulo.1a ed. São Paulo: FAUUSP, 2017, v.1, p. 18-32.

BRANDAO, B.B.; BUENO, L.M.M. Intervenções de mobilidade e acessibilidade em programas de urbanização de favelas: análise em São Paulo e Rio de Janeiro de 1996 a 2012. Arquitetura Revista, v.14, n.2, 2018. Disponível em: http://revistas.unisinos.br/index.php/arquitetura/article/view/arq.2018.142.11/0. Acesso em: 16 jul. 2020.

BRANDAO, A.J.D.N.; LEITAO, K.O. O componente ambiental nas transformações físico-urbanísticas na favela do Jaguaré. In: ZUQUIM, M.L; SANCHEZMAZO, L. Barrios populares Medellín: favelas São Paulo.1a ed. São Paulo: FAUUSP, 2017, v.1, p. 18-32.

BUENO, L.M.M. O desafio da universalização do saneamento. Reconhecer na cidade os padrões espaciais regulares e irregulares. Arquitextos, São Paulo, ano 19, n. 226.01, Vitruvius, mar. 2019 Disponível em: <https://www.vitruvius.com.br/revistas/read/arquitextos/19.226/7308>. Acesso em 20 jul 2020.

CARDOSO, A; DENALDI, R. (orgs.) Urbanização de favelas no Brasil: um balanço preliminar do PAC. Rio de Janeiro: Letra Capital, 2018. Disponível em https://www.observatoriodasmetropoles.net.br/wp-content/uploads/2019/06/Adauto-CARDOSO-e-Rosana-DENALDI-Urbaniza\%C3\%A7\%C3\%A3o-de-favelas-no-Brasil.pdf. Acesso em: 20 jul. 2020.

COELHO, C. B. Melhorias habitacionais em favelas urbanizadas: impasses e perspectivas [doi:10.11606/D.16.2018.tde-08062017-103739]. São Paulo: Faculdade de Arquitetura e Urbanismo, Universidade de São Paulo, 2017. Dissertação de Mestrado em Habitat. Acesso em: 25 nov. 2019.
DENALDI, R. Políticas de Urbanização de Favelas: evolução e impasses, 2003. p. 190-194. Tese - Doutorado em Habitat, Faculdade de Arquitetura e Urbanismo, Universidade de São Paulo, São Paulo, 2003. Disponível em: <pucsp.br/ecopolitica/downloads/tes 2003 Politicas urbanizacao impasses.pdf> Acesso em: 25 jan. 2020.

DENALDI, R.; FERRARA, L. N. A Dimensão Ambiental da Urbanização em Favelas. Ambient. soc., São Paulo, v. 21, e01950, 2018. Disponível em: http://www.scielo.br/scielo.php?script=sci arttext\&pid=S1414753X2018000100315\&lng=pt\&nrm=iso. Acesso em: 23 jul. 2020. Epub 08-Out-2018. https://doi.org/10.1590/1809-4422asoc0195rovu1811ao.

FERRARA, L. N.; FURIGO, R. F. R.; MORETTI, R. S.; SAMORA, P. R. Saneamento Básico e Urbanização de Favelas: os desafios para a universalização à luz das especificidades de ocupação dos assentamentos precário In: FERREIRA, L.; OLIVEIRA, P.; LACOVINI, V. (Org.). Dimensões do intervir em favelas: desafios e perspectiva. 1. ed. São Paulo: Peabiru TCA, 2019. p. 111-118.

INSTITUTO BRASILEIRO DE GEOGRAFIA E ESTATISTICA. Aglomerados Subnormais 2019: Classificação preliminar e informações de saúde para o enfrentamento à COVID-19. 1. ed. rj,2020. Disponível em: biblioteca.ibge.gov.br/index.php/biblioteca-catalogo?view=detalhes\&id=2101717. Acesso em: 21 jun. 2020.

INSTITUTO LOCOMOTIVA. Moradores de favela movimentam R $\$ 119,8$ bilhões por ano. [Publicado em 28 jan 2020] Disponível em: ilocomotiva.com.br/singlepost/2020/01/28/AG \%C3\%8ANCIA-BRASIL-Moradores-de-favelas-movimentamR-1198-bilh\%C3\%B5es-por-ano. Acesso em: 23 jul. 2020.

MARICATO, E. Metrópole na periferia do capitalismo. llegalidade, desigualdade e violência. São Paulo: Hucitec, 1996.

MARICATO, E. Brasil, cidades. Alternativas para a crise urbana. São Paulo: Vozes, 2001.

MARICATO, E. Reforma urbana é direito a cidade. Entrevista concedida à Davi Carvalho em 1/10.2014. Disponível em: https://erminiamaricato.net/2014/10/08/reforma-urbana-e-direito-a-cidade/. Acesso em 19/12/2020. 
MAZIVIERO, M.C.; SILVA, A.S. O caso do Complexo Paraisópolis em gestões: diferenças conceituais em programas de intervenção em favelas em São Paulo. urbe, Rev. Bras. Gest. Urbana, Curitiba, v. 10, n. 3, p. 500-520, dez. 2018. Disponível em: $\quad$ http://www.scielo.br/scielo.php?script=sci arttext\&pid=S217533692018000300500\&lng=pt\&nrm=iso. $\quad$ Acesso em: 23 jul. 2020. Epub 04-Jun-2018. https://doi.org/10.1590/21753369.010.003.ao03.

MISTURA, R. B. Urbanização de assentamentos precários junto à cursos d'água: os princípios das ações do BID e do PAC nas intervenções em Áreas de Preservação Permanente. Dissertação (Mestrado em Arquitetura e Urbanismo). 2019. Pontifícia Universidade Católica de Campinas, Programa de Pós-Graduação em Arquitetura e Urbanismo, Campinas, 2019.

OLIVEIRA, F. Crítica à razão dualista. São Paulo: Boitempo editorial, 2003 [1972]

PREFEITURA MUNICIPAL DE SÃO PAULO, SECRETARIA MUNICIPAL DE HABITAÇAO. Plano Municipal de Habitação de São Paulo, 2016. Disponível em: gestaourbana.prefeitura.sp.gov.br/wpcontent/uplo-

ads/2014/08/20161221 PMH PL bxa.pdf. Acesso em: 21 jan. 2020.

PETRAROLLI, J. O tempo nas urbanizações de favelas: contratação e execução de obras do PAC no Grande ABC. Dissertação (Mestrado em Planejamento e Gestão do Território). Universidade Federal do ABC, Santo André, 2015.

PREFEITURA MUNICIPAL DE SÃO PAULO; INSTITUTO DE ARQUITETOS DO BRASIL. Edital do concurso RENOVA SP, concurso n. 001/2011. São Paulo: Secretaria Municipal de Habitação - SEHAB, 2011. Disponível em: https://drive.google.com/file/d/15CJaosqScY-NIHFiF9EIYV--6KMqMbJq/view. Acesso em: 19 set. 2019.

PREFEITURA MUNICIPAL DE SÃO PAULO, SECRETARIA MUNICIPAL DE HABITAÇAO. Programa de Urbanização de Favelas São Paulo: Secretaria Municipal de Habitação - SEHAB, 2009. Disponível em: https://www.prefeitura.sp.gov.br/cidade/secretarias/habitacao/programas/index.php?p=3374. Acesso em: 21 jan. 2020 .
SAMORA, P. R. Projeto de Habitação em Favelas: Especificidades e parâmetros de qualidade. 2010. $347 \mathrm{f}$. Tese - Doutorado em Habitat, Faculdade de Arquitetura e Urbanismo, Universidade de São Paulo, São Paulo, 2010. Disponível em: doi:10.11606/T.16.2010.tde-27042010-151732. Acesso em: 30 set. 2019.

SAMORA, P.R., ZUQUIM, M.L. Desafios da urbanização de assentamentos precários em São Paulo. In: ZUQUIM, M.L; SANCHEZ-MAZO, L. Barrios populares Medellín: favelas São Paulo.1a ed. São Paulo: FAUUSP, 2017, v.1, p. 66-77.

TOI, S.F. Dinâmicas de apropriação dos espaços públicos na Vila Nova Jaguaré. In: ZUQUIM, M.L; SANCHEZ-MAZO, L. Barrios populares Medellín: favelas São Paulo.1a ed. São Paulo: FAUUSP, 2017, v.1, p. 178-191.

VILLAÇA, F. O espaço intra-urbano no Brasil. São Paulo: Studio Nobel, 1998.

VOSGUERITCHIAN, A. B.; SAMORA, P. R. Acesso solar e adensamento em favelas. Anais do II Congresso Brasileiro e I lberoamericano Habitação Social, Ciência e Tecnologia Florianópolis, 2006. Disponível em: https:/www.academia.edu/2570790/Acesso_solar_e_adensamento_em_favelas. Acesso em: 15 out. 2019.

ZUQUIM, M. L. Urbanização de assentamentos precários no município de São Paulo: quem ganha e quem perde? In: II Encontro da Associação Nacional de Pesquisa e Pós-graduação em Arquitetura e Urbanismo. II ENANPARQ: Teorias e práticas na arquitetura e na cidade contemporâneas: complexidade, mobilidade, memória e sustentabilidade. Anais. Natal (Brasil): Universidade Federal do Rio Grande do Norte, 2012

ZUQUIM, M. L.; NOGUEIRA, F. R.; MORETTI, R. de S. ; CANIL, K. . Remanescência da ilegalidade, da irregularidade, da precariedade e dos riscos pós-urbanização de favelas. Submetido para: II Seminário Nacional de Urbanização de Favelas. II URBFAVELAS. Anais. Rio de Janeiro (Brasil): Universidade Estadual do Rio de Janeiro, 2016. 